University of Nebraska - Lincoln

DigitalCommons@University of Nebraska - Lincoln

Faculty Publications: Department of

Entomology

Entomology, Department of

$9-18-2002$

\title{
Dynamic change in photosynthetic pigments and chlorophyll degradation elicited by cereal aphid feeding
}

\author{
Xinzhi Ni \\ Montana State University, Bozeman, MT \\ Sharron S. Quisenberry \\ Montana State University, Bozeman, MT \\ Tiffany Heng-Moss \\ University of Nebraska-Lincoln, thengmoss2@unl.edu \\ John P. Markwell \\ University of Nebraska-Lincoln, jmarkwell2@unl.edu \\ Leon G. Higley \\ University of Nebraska-Lincoln, Ihigley1@unl.edu
}

See next page for additional authors

Follow this and additional works at: https://digitalcommons.unl.edu/entomologyfacpub

Part of the Entomology Commons

Ni, Xinzhi; Quisenberry, Sharron S.; Heng-Moss, Tiffany; Markwell, John P.; Higley, Leon G.; Baxendale, Frederick P.; Sarath, Gautam; and Klucas, Robert, "Dynamic change in photosynthetic pigments and chlorophyll degradation elicited by cereal aphid feeding" (2002). Faculty Publications: Department of Entomology. 130.

https://digitalcommons.unl.edu/entomologyfacpub/130

This Article is brought to you for free and open access by the Entomology, Department of at DigitalCommons@University of Nebraska - Lincoln. It has been accepted for inclusion in Faculty Publications: Department of Entomology by an authorized administrator of DigitalCommons@University of Nebraska - Lincoln. 


\section{Authors}

Xinzhi Ni, Sharron S. Quisenberry, Tiffany Heng-Moss, John P. Markwell, Leon G. Higley, Frederick P.

Baxendale, Gautam Sarath, and Robert Klucas 
Published in Entomologia Experimentalis et Applicata 105 (2002), pp. 43-53.

Copyright @ 2002 Kluwer Academic Publishers. http://www.springerlink.com/content/102876/ Used by permission.

Accepted September 18, 2002

\title{
Dynamic change in photosynthetic pigments and chlorophyll degradation elicited by cereal aphid feeding
}

\author{
Xinzhi Ni ${ }^{1}$, Sharron S. Quisenberry ${ }^{1}$, Tiffany Heng-Moss², John Markwell ${ }^{3}$, \\ Leon Higley², Frederick Baxendale², Gautam Sarath ${ }^{3}$, and Robert Klucas ${ }^{3}$ \\ ${ }^{1}$ Department of Entomology, Montana State University, Bozeman, MT 59717, USA (Phone: (406) 994-7626; Fax: \\ (406) 994-6029; E-mail: xni@montana.edu) \\ ${ }^{2}$ Department of Entomology, and \\ ${ }^{3}$ Department of Biochemistry, University of Nebraska-Lincoln, Lincoln, NE 68583, USA
}

\begin{abstract}
The concentration of photosynthetic pigments (i.e., chlorophylls $a$ and $b$, and carotenoids) and chlorophyll degradation enzyme (i.e., chlorophyllase, oxidative bleaching, and Mg-dechelatase) activities on aphid-damaged and non-damaged regions of the infested leaves were determined with two infestation periods (6 and 12 days). Russian wheat aphid [Diuraphis noxia (Mordvilko) (Hemiptera: Aphididae)] feeding caused significant losses of chlorophylls $a$ and $b$ and carotenoids in the damaged regions. However, bird cherry-oat aphid [Rhopalosiphum padi (L.) (Hemiptera: Aphididae)] feeding did not, except a significantly lower level of carotenoids was observed in the damaged regions from the short-infestation (6-day) samples. Interestingly, the non-damaged regions of $D$. noxia-infested leaves on both sampling dates had a significant increase of chlorophylls $a$ and $b$ and carotenoid concentrations when compared with the uninfested leaves. Although $D$. noxia feeding did not cause any changes in either chlorophyll $a / b$ or chlorophyll $(a+b)$ /carotenoid ratio between the damaged and non-damaged leaf regions on short-infestation (6-day) samples, a significantly lower chlorophyll $a / b$ ratio was detected in long-infestation (12-day) samples. The assays of chlorophyllase and oxidative bleaching activities showed no significant differences between the damaged and nondamaged regions of the infested leaves on either sampling date. Mgdechelatase activity, however, was significantly higher in $D$. noxia-damaged than non-damaged leaf regions from the short-infestation samples, while no differences were detected from the long-infestation samples. Furthermore, the long-infestation samples showed that Mg-dechelatase activity from both $D$. noxia-damaged and non-damaged regions increased significantly in comparison with the respective regions of either uninfested or $R$. padi-infested leaves. We infer that non-damaged regions of $D$. noxia-infested leaves compensate for the pigment losses in the damaged regions, and that Mg-dechelatase activity changed dynamically from a localized response to a systemic response as infestation duration extends. The findings from this study on cereal aphid-elicited chlorosis (or desistance) would help us to elucidate plant resistance mechanisms, in particular plant tolerance to non-defoliating herbivory.
\end{abstract}

Keywords: chlorophylls $a$ and $b$, carotenoids, chlorophyllase, oxidative bleaching, Mg-dechelatase, Russian wheat aphid, bird cherry-oat aphid, Aphididae, Hemiptera, plant resistance, herbivory

\section{Introduction}

Chlorophyll catabolism is equal to global chlorophyll synthesis, which is estimated at a billion tons per year (Rüdiger, 1997; Tsuchiya et al., 1999). Chlorophyll loss can be further differentiated into two types of chlo- rophyll catabolism. One is senescent chlorophyll catabolism occurring in the autumn leaves, and the other is leaf chlorosis in growing plants that is elicited by insect feeding, nutritional deficiencies, or pathogen-infections. The former type has been studied during the last few decades (Rüdiger, 1997; Matile et al., 1999). Natu- 
ral chlorophyll $a$ degradation in senescent plants occurs by one of two pathways: one is pheophorbide $a$ pathway (Matile et al., 1999) and the other is oxidative bleaching pathway (Janave, 1997). Three in vitro enzyme assays for quantifying chlorophyllase, oxidative bleaching, and Mg-dechelatase activities involved in the two pathways have been described previously (Vicentini et al., 1995; Janave, 1997). In contrast, herbivore-or pathogen-elicited leaf chlorosis in growing plants is not well understood. We have adopted the enzyme assays developed using senescent plants to assess Russian wheat aphid [Diuraphis noxia (Mordvilko) (Hemiptera: Aphididae)]-elicited leaf chlorosis in young wheat seedlings. One of our previous studies showed that the feeding of chlorosis-eliciting $D$. noxia or non-chlorosis-eliciting bird cherry-oat aphid [Rhopalosiphum padi (L.) (Hemiptera: Aphididae)] did not cause any changes in oxidative bleaching pathway or chlorophyllase activity in comparison with the uninfested plants (Ni et al., 2001). However, D. noxia-infested wheat leaves showed significantly greater Mg-dechelatase activity than $R$. padi-infested and uninfested wheat leaves. The results led us to further examine how the substrate (i.e., chlorophyllide) was supplied for the greater Mg-dechelatase activity when chlorophyllase activity in the pheophorbide a pathway was not affected by aphid feeding (Ni et al., 2001). In addition, because we used whole leaf extracts for assaying the three enzyme activities, the enzymatic changes between chlorotic and green regions within an infested leaf-blade could not be determined. The enzymatic changes between the damaged and non-damaged regions of the wheat leaf blades at different sampling dates would provide us with further insights on localized chlorophyll loss. The variation in Mg-dechelatase activity between the damaged and non-damaged regions of an infested leaf is also not known.

The objectives of the present research were to quantify photosynthetic pigment (i.e., chlorophylls $a$ and $b$, and carotenoids) concentrations, and assay chlorophyll degradation enzyme (i.e., chlorophyllase, oxidative bleaching, and Mg-dechelatase) activities between the aphid-injured and non-injured regions of aphid-infested wheat leaves. This was a follow-up research of the report by $\mathrm{Ni}$ et al. (2001) to elucidate further spatial and temporal details in the aphid-elicited changes in photosynthetic pigment concentrations and chlorophyll degradation in wheat plants. This research would provide us with critical information about $D$. noxia-elicited chlorosis (or desistance) formation. The information would, in turn, help us to unravel the mechanisms of plant tolerance to non-defoliating herbivory.

\section{Materials and methods}

Plants and insects. 'Arapahoe' (D. noxia susceptible) wheat (Triticum aestivum L.) was used for this experiment. Seeds of Arapahoe wheat were planted at the rate of three plants per Conetainer ${ }^{\mathrm{TM}}(3.81 \mathrm{~cm}$ diameter by $21 \mathrm{~cm}$ depth) (Stuewe \& Sons, Inc., Corvallis, OR) in the Plant Growth Center at Montana State University. The Conetainers ${ }^{\mathrm{TM}}$ were filled with Sunshine ${ }^{\mathrm{TM}}$ soil mix and placed in Conetainer ${ }^{\mathrm{TM}}$ racks, leaving one space among Conetainers ${ }^{\mathrm{TM}}$ to provide adequate light. Plants were watered uniformly from the bottom by placing a rack over a plastic tray $(54 \times 28 \times 6 \mathrm{~cm})$ filled with water. Before the initiation of aphid infestation, the plants were thinned to two plants per Conetainer ${ }^{\mathrm{TM}}$. The wheat plants were maintained in a growth chamber at L16:D8 and $21^{\circ} \mathrm{C}$.

Both chlorosis-eliciting and non-chlorosis-eliciting aphid colonies were established using field-collected aphids. The colony of chlorosis-eliciting $D$. noxia was established originally using the aphids collected near Scottsbluff, NE, in 1994, while the non-chlorosiseliciting $R$. padi colony was established using aphids collected near Lincoln, NE, in 1996. The aphid colonies on 'Stephens' wheat plants were maintained in Plexiglas cages $(30 \times 15 \times 15 \mathrm{~cm})$ in two separate Percival ${ }^{\mathrm{TM}}$ growth chambers (Percival Scientific, Boone, IA) at 21 $\pm 1^{\circ} \mathrm{C}$, a photoperiod of L16:D8, and $40-50 \%$ r.h.

\section{Aphid infestation and plant sample collection}

There were three types of infestations (or treatments) for the experiment; ten $D$. noxia adults, ten $R$. padi adults, or zero aphid per plant (as control). The experiment was initiated when the Arapahoe wheat plants reached the 3-leaf stage [stage 13 of the Zadoks' scale (Zadoks et al., 1974)]. The uninfested and the aphid-infested wheat plants in Conetainers ${ }^{\mathrm{TM}}$ were caged using polyethylene tube-cages (30-cm length by 4-cm diameter) and maintained in a growth chamber under the conditions as described previously. Because the biomass of either chlorotic or green region on a $D$. noxia-infested plant was small, 12 plants (or six Conetainers ${ }^{\mathrm{TM}}$ ) were sampled simultaneously for enzyme assays on each sampling date. We sampled 12 plants from six Conetainers $^{\mathrm{TM}}$ instead of sampling one plant from all 12 Cone- 
tainers $^{\mathrm{TM}}$ for each infestation on each sampling date. The reason of using this sampling regime was to minimize the disturbance on aphid population caused by sampling. If we sampled one plant from each Conetainer ${ }^{\mathrm{TM}}$, the accurate aphid biomass on the 6-day sampling could not be collected, because $D$. noxia could easily fall off from both plants during the sampling process, while $R$. padi could be found on wheat plants as well as on the cages. In either case, it was difficult to determine the aphids belonged to which one of the two plants in the Conetainer $^{\mathrm{TM}}$. Both aphids and wheat leaves from the experimental plants were collected separately 6 and 12 days after the initial infestation. The 6-day samples were considered short-infestation samples, while the 12-day samples were considered long-infestation samples.

On each sampling date, after aphids were brushed off and weighed on a electric scale, the leaf samples were processed. Chlorotic and green leaf regions on each $D$. noxia-infested plant were harvested separately as the subtreatments (i.e., aphid-injured and non-injured). Although leaf chlorosis was not observed in either uninfested or $R$. padi-infested plants, we partitioned the equivalent leaf regions that showed chlorosis and nonchlorosis in D. noxia-infested plants as the two subtreatments (i.e., partitioned injured and partitioned noninjured). Because plant pigments and related enzyme activities usually vary by its tissue age (Boffey et al., 1980), the partitioning of the two sub-treatments in the uninfested treatment is necessary. By using the leaves with same age and position that only differed in aphid injury, we were able to avert the confounding differences in $D$. noxia and $R$. padi aggregating and feeding preferences, and to demonstrate only aphid injury symptom-related spatial changes within wheat leaves. Separated leaf samples were weighed and stored at $-20{ }^{\circ} \mathrm{C}$ for quantifying leaf chlorophylls, carotenoids, and chlorophyll degradation enzyme activities.

\section{Chlorophyll and carotenoid quantification from wheat leaf samples}

Chlorophyll from aphid-damaged and non-damaged samples was extracted and determined using $80 \%$ acetone. The concentrations of chlorophylls $a$ and $b$ and total carotenoids were calculated using the formulas described by Bertrand \& Schoefs (1997). A separate (or duplicate) set of plant samples were used for chlorophyll and carotenoid determinations because the chlorophylls extracted using $n$-butanol during enzyme ex- traction could not be used for accurate chlorophyll determination.

The chlorophyll $a / b$ ratio was calculated to assess the impact of aphid feeding on plant photosynthetic capacity. Because chlorophyll catabolism in the senescent leaves unmasks carotenoids in plant foliage (Dangl et al., 2000), chlorophyll $(a+b)$ /carotenoid ratio was used to determine the impact of aphid-elicited chlorosis on plant normal development.

Extraction of plant enzymes. The enzyme extractions from the wheat leaf samples were conducted according to Mihailović et al. (1997) modified using Ellsworth (1971), Drążkiewicz (1994), and Janave (1997). The plants (1.0 to $4.0 \mathrm{~g}$ ) were ground with liquid nitrogen in a mortar and pestle. Ten $\mathrm{ml}$ of chilled extraction buffer containing $0.1 \mathrm{M}$ potassium phosphate buffer $(\mathrm{pH}$ 6.2 ), $1 \% \mathrm{NaCl}, 1 \%$ Triton $\mathrm{X}-100$, and $1 \%$ polyvinylpyrrolidone (PVP) were used for all plant materials. Plant homogenates were filtered through Miracloth ${ }^{\mathrm{TM}}$. Chlorophylls were then removed using one volume of n-butanol and centrifuged at 3,000 $\times g$ for $3 \mathrm{~min}$. The protein in the lower (aqueous) layer was then collected, and precipitated with two volumes of cold $\left(4^{\circ} \mathrm{C}\right)$ acetone. After the addition of acetone, the samples were swirled briefly and allowed to stand for $5 \mathrm{~min}$ on ice. The samples were then centrifuged at $5,000 \times g$ for $5 \mathrm{~min}$, the precipitate was normalized by re-suspending it in $1 \mathrm{ml}$ of $0.1 \mathrm{M}$ potassium phosphate buffer ( $\mathrm{pH} 7.0$ ), and kept at $4{ }^{\circ} \mathrm{C}$ for $2 \mathrm{~h}$ before the initiation of enzyme assays. Only freshly prepared samples were used for enzyme assays.

Preparation of chlorophylls and chlorophyllins for enzyme assays. Fresh spinach leaves were used for chlorophyll extraction according to Janave (1997). After spinach leaves were macerated in chilled acetone, the extracts were filtered through Whatman No. 2 filter paper and then centrifuged at $6,000 \times g$ for $10 \mathrm{~min}$ to remove insoluble materials in the filtrates. The supernatant was then purified twice by dioxane precipitation (Iriyama et al., 1974; Janave, 1997). The ratio of dioxane:acetone was $1: 7(\mathrm{v} / \mathrm{v})$ and distilled water was added drop-wise, with stirring until the precipitates formed. The precipitated chlorophylls were then centrifuged at 3,000 $\times g$ for $3 \mathrm{~min}$ and resuspended in acetone. The concentrations of chlorophylls $a$ and $b$ were determined by the dilution of original chlorophyll solution with $80 \%$ acetone according to the formulas described by Bertrand \& Schoefs (1997) using A646 nm and A663 nm. The chlorophyll 
solution was stored in the dark at $-20{ }^{\circ} \mathrm{C}$ until used as a substrate for chlorophyll degradation and chlorophyllase activity assays.

Chlorophyllins were prepared from chlorophylls by Molisch conversion as described by Vicentini et al. (1995). One hundred $\mu \mathrm{l}$ of $30 \% \mathrm{KOH}$ in methanol was added to $12 \mathrm{ml}$ of chlorophyll solution in petroleum ether. The precipitated chlorophyllins were centrifuged at 3,000 $\times g$ for $5 \mathrm{~min}$ and dissolved in $10 \mathrm{ml}$ of distilled water by bringing to $\mathrm{pH} 9$ with tricine. Chlorophyllins were stable at $\mathrm{pH} 9$ when stored in the dark at $-20{ }^{\circ} \mathrm{C}$. Chlorophyllins were used as the substrates for Mg-dechelatase assays.

Chlorophyll degradation assay. The loss of chlorophylls $a$ and $b$ was measured according to the method used by Janave (1997). The reaction mixture $(1.0 \mathrm{ml})$ contained $0.36 \mathrm{ml} 0.1 \mathrm{M}$ potassium phosphate buffer $(\mathrm{pH}$ 7.0 ), $0.288 \mathrm{ml}$ of acetone (to make $30 \%$ in final reaction mixture), $12 \mu \mathrm{l}$ of chlorophyll in acetone (to make $10 \mu \mathrm{M}$ of chlorophyll $a$ in final reaction mixture), and $0.34 \mathrm{ml}$ of the enzyme extracts. The mixture was incubated at $30{ }^{\circ} \mathrm{C}$ in a water bath under the dark for 30 min. The control incubation did not contain enzyme extracts. The reaction was stopped by adding $0.1 \mathrm{ml}$ of $1 \mathrm{~N}$ $\mathrm{NaOH}$ followed by $3 \mathrm{ml}$ acetone/hexane mixture (1/2, v/ v). The reaction mixture was then vortexed vigorously until emulsion formation, allowed to stand for $10 \mathrm{~min}$, and centrifuged at $3,000 \times g$ for 5 min. Absorbance of the hexane layer at $663 \mathrm{~nm}$ was recorded. Chlorophyll $a$ concentration was determined by employing the specific absorption coefficient of $94.5 \mathrm{M}^{-1} \cdot \mathrm{cm}^{-1}$. Activity was expressed by $\mu \mathrm{mol}$ of chlorophyll $a$ degraded per $\mathrm{g}$ fresh weight during the $30 \mathrm{~min}$ of incubation (or $\mu \mathrm{mol} \cdot 30$ $\min ^{-1} \bullet \mathrm{g}^{-1}$ fresh leaf weight). The activities determined by this procedure include both chlorophyllase and chlorophyll oxidase bleaching pathways (Janave, 1997).

Chlorophyllase activity. We have modified the procedure reported by Janave (1997) based on Tanaka et al. (1982). The enzyme solution was incubated in $1.0 \mathrm{ml}$ of reaction mixture containing $0.35 \mathrm{ml}$ of $0.1 \mathrm{M}$ potassium phosphate buffer ( $\mathrm{pH} 7.0$ ), $0.288 \mathrm{ml}$ of acetone (to make $30 \%$ in final concentration), $0.01 \mathrm{ml}$ of $0.1 \mathrm{M}$ ascorbate, and $12 \mu \mathrm{l}$ chlorophyll (for final concentration of $10 \mu \mathrm{M}$ ). The reaction was initiated by adding $0.34 \mathrm{ml}$ enzyme extracts. After $30 \mathrm{~min}$ at $30^{\circ} \mathrm{C}, 0.1$ $\mathrm{ml}$ of $1 \mathrm{~N} \mathrm{NaOH}$ was added to stop the reaction. Then, 3 $\mathrm{ml}$ of acetone/n-hexane $(1: 2 \mathrm{v} / \mathrm{v})$ was added to the reac- tion mixture. The reaction mixture was then vigorously shaken so that the chlorophyllide formed by the enzymatic reaction was partitioned into the lower aqueous layer. The mixture was then centrifuged at $3,000 \times g$ for $5 \mathrm{~min}$. The enzyme activity was determined by measuring the decrease of chlorophyll $a$ using the absorbance change at $663 \mathrm{~nm}$ and expressed as $\mu \mathrm{mol}$ of chlorophyll $a$ degraded during $30 \mathrm{~min}$ incubation $\left(\mu \mathrm{mol} \cdot 30 \mathrm{~min}^{-1}\right.$ $\cdot \mathrm{g}^{-1}$ fresh leaf weight).

Oxidative chlorophyll bleaching activity. The presence of oxidative enzymes (e.g., chlorophyll oxidase) catalyzing chlorophyll degradation was examined by conducting an enzyme assay using ascorbate as inhibitor for oxidative bleaching (Janave, 1997). Degradation of chlorophylls without the inhibitor indicated the results of both chlorophyllase and oxidative bleaching pathways. However, the absorbance change obtained in the presence of $2 \mathrm{mM}$ ascorbate indicates only chlorophyllase pathway, because the addition of ascorbate in the reaction mixture totally inhibits the oxidative bleaching pathway (Janave, 1997). The contribution of oxidative bleaching pathway to overall chlorophyll degradation was calculated by subtracting the absorbance change with the inhibitor from the absorbance change without the inhibitor.

Mg-dechelatase activity. The dechelation of magnesium from chlorophyllin (or chlorophyllide) to form pheophorbide was determined by monitoring the change in absorbance with time at $686 \mathrm{~nm}$ according to Vicentini et al. (1995) and Janave (1997). The assay mixture was comprised of $830 \mu \mathrm{l} 50 \mathrm{mM}$ Tris-Tricine ( $\mathrm{pH} 8.0$ ), $50 \mu \mathrm{l}$ chlorophyllin $\left(\mathrm{A}_{686 \mathrm{~nm}}=0.18\right), 100 \mu \mathrm{l}$ of $1 \%$ Triton X-100, and $20 \mu \mathrm{l}$ of enzyme extract. A control mixture did not contain plant enzyme extract. The reaction was carried out at $25{ }^{\circ} \mathrm{C}$ for 2 min and activity was expressed as $\Delta \mathrm{A}_{686} \mathrm{~min}^{-1} \mathrm{~g}^{-1}$ fresh leaf weight. The decrease of substrate chlorophyllin and the increase of pheophorbide were confirmed spectrophotometrically according to the protocol described by Janave (1997). The identity of chlorophyllin and pheophorbide was further confirmed using a reverse-phase high performance liquid chromatograph (System 5004, Isco Inc., Lincoln, $\mathrm{NE}$ ) according to the protocol described by Almela et al. (2000).

Protein determination. Protein concentration of all leaf samples was determined according to the dye binding 
Table 1. Aphid biomass (g) $( \pm \mathrm{SEM})$ on twelve 'Arapahoe' wheat plants used in the enzyme assays

\begin{tabular}{lll}
\hline \multirow{2}{*}{ Treatments } & \multicolumn{2}{c}{ Days after infestation $^{\mathrm{a}}$} \\
\cline { 2 - 3 } & 6 days & 12 days \\
\hline Uninfested & 0 & 0 \\
D. noxia & $0.091 \pm 0.011 \mathrm{a} \mathrm{X}$ & $0.429 \pm 0.021$ a Y \\
R. padi & $0.089 \pm 0.012 \mathrm{a} \mathrm{X}$ & $0.272 \pm 0.017 \mathrm{~b} \mathrm{Y}$ \\
\hline
\end{tabular}

${ }^{a}$ Means without standard error of mean (SEM) denoted SEM $=0$. The means listed in the table were calculated from ten aphid samples $(n=10)$. Each aphid sample was from 12 plants on a sampling date. Means with different letters within a column (a-b) (i.e., the same sampling date) were significantly different ( $t$-test, $\alpha=0.05$ ), and means with different letters within a row (X$\mathrm{Y})$ were significantly different.

assay (Bollag \& Edelstein, 1991) using bovine serum albumin as a standard.

Experimental design and data analysis. The experiment had three treatments (zero, ten $D$. noxia, or ten $R$. padi) of Arapahoe wheat and sampled on days 6 and 12 after the initial infestation. Because of the small leaf blades of wheat seedlings, 12 plants were used for each treatment on each sampling date. Injured and non-injured regions of the infested wheat leaves were separated as two sub-treatments within each treatment. While the experiment was repeated four times for the photosynthetic pigment determination, the experiment was repeated ten times for chlorophyll degradation enzyme activity assays. The data from the experiment were analyzed as a repeated measures design, using the PROC GLM procedure of the SAS software (SAS Institute, 1989) with TEST statements. The means from the two sub-treatments were compared using the paired $t$-test, while the means among the infestation types and durations were separated using the LSD test $(\alpha=0.05)$.

\section{Results}

Aphid biomass. Although the plants used in the experiment were infested with the same number (ten) of $D$. noxia or $R$. padi, the two aphid species showed different reproduction potential demonstrated by aphid biomass (Table 1). Aphid biomass was significantly affected by aphid species ( $\mathrm{F}=15.48$, $\mathrm{df}=1,9, \mathrm{P}=0.0034)$ and infestation duration $(\mathrm{F}=569.15, \mathrm{df}=1,18, \mathrm{P}<0.0001)$. Aphid biomass was also significantly affected by aphid species by sampling date interaction $(\mathrm{F}=51.06 \mathrm{df}=$ $1,18, \mathrm{P}<0.0001)$. Although there was no difference in aphid biomass on day 6 , there was a significant difference on day 12 (Table 1). The aphid biomass data indicated $D$. noxia produced significantly more nymphs than $R$. padi. The data also indicated that aphid biomass was related to both aphid species and infestation duration.

Chlorophylls $a$ and $b$ and carotenoid concentrations. Aphid infestation type and duration significantly affected plant pigment levels irrespective of the damaged or nondamaged leaf regions (Figures 1-3). Diuraphis noxia infestation caused significant loss of chlorophyll $a$ in comparison with either uninfested or $R$. padi-infested plants $(\mathrm{F}=6.15, \mathrm{df}=2,6, \mathrm{P}=0.0352)$ (Figures $1 \mathrm{~A}, \mathrm{~B})$ and infestation duration $(\mathrm{F}=41.67$, $\mathrm{df}=1,18, \mathrm{P}<0.0001)$. The infestation type by duration interaction also significantly ( $\mathrm{F}=7.91$, $\mathrm{df}=2,18, \mathrm{P}<0.0034)$ affected chlorophyll $a$ concentration. Chlorophyll $b$ (Figures 2A, B) and carotenoid (Figures 3A, B) concentrations were similarly impacted by infestation type and duration, and infestation type-by-duration interactions (P-values $<0.05$ ) when compared with chlorophyll $a$ (Figures 1A, B).

Chlorophyll $a$ concentration from $D$. noxia-damaged regions was significantly lower than the non-damaged on day $6(\mathrm{t}=24.97, \mathrm{df}=3, \mathrm{P}<0.0154)$ (Figure $1 \mathrm{~A})$ and day $12(\mathrm{t}=39.95$, $\mathrm{df}=3, \mathrm{P}<0.0080)$ (Figure $1 \mathrm{~B})$. Chlorophyll $b$ (Figures 2A, B) and carotenoids (Figures 3A, B) were also similarly impacted by $D$. noxia infestation on both sampling dates $(\mathrm{P}<0.05)$. There were no significant differences in chlorophyll $a$ or $b$ concentrations between $R$. padi-infested and uninfested regions ( $\mathrm{P}$ values $>0.05$ ) (Figures 1A, B and Figures 2A, B). However, carotenoid concentration from $R$. padidamaged regions was significantly $(\mathrm{F}=12.19, \mathrm{df}=1,3, \mathrm{P}=0.0397)$ lower than the non-damaged regions on day 6 (Figures 3A, B).

Further comparisons of aphid-damaged regions among the three-infestation types (indicated by black bars in Figures 1-3) showed that $D$. noxia feeding caused significant losses of all photosynthetic pigments on both dates (P-values < 0.05), except that no differences were found in carotenoid concentrations $(F=4.45$, $\mathrm{df}=2,6, \mathrm{P}=0.0653$ ) on day 12 . In contrast, the three photosynthetic pigment concentrations from the nondamaged leaf regions of $D$. noxia-infested plants (Figures 1-3) were significantly higher than the equivalent regions of the uninfested leaves (P-values $<0.05$ ). The results indicated that non-damaged regions of $D$. noxiainfested leaves compensated for photosynthetic pigment losses in the damaged regions. 

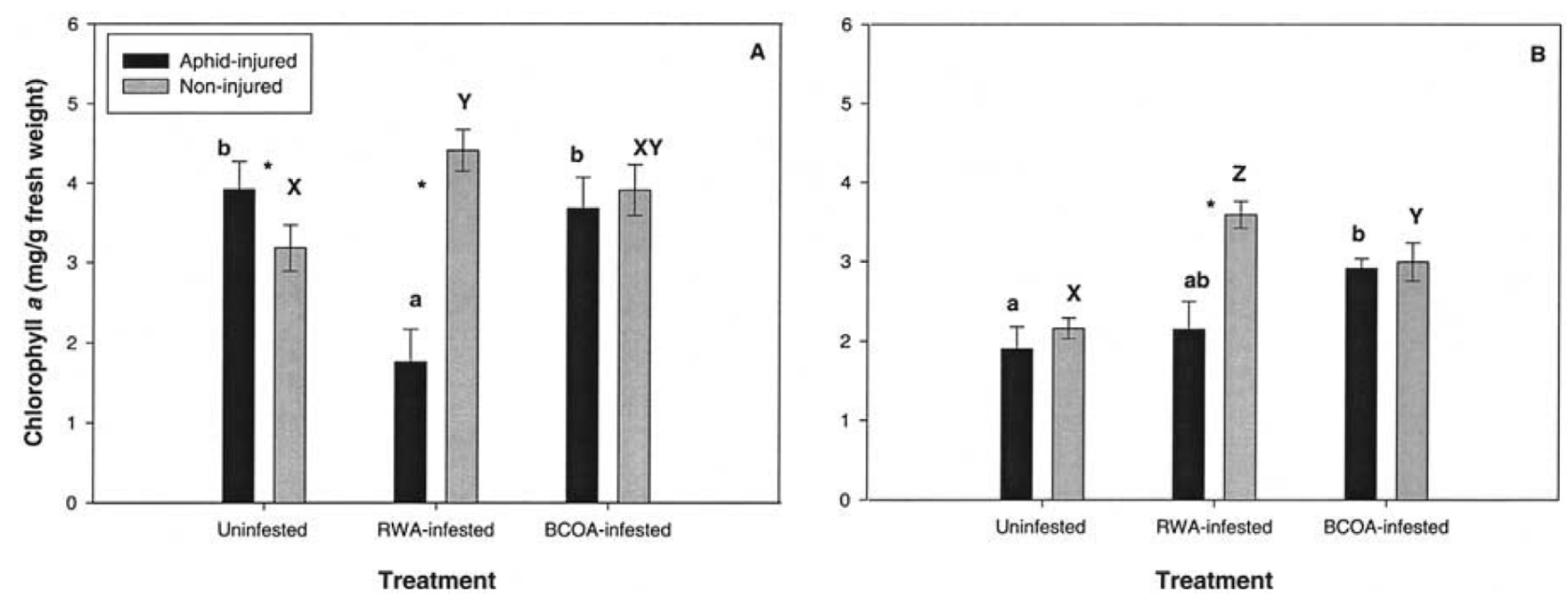

Figure 1. Chlorophyll $a$ concentration ( $\mathrm{mg} \cdot \mathrm{g}^{-1}$ fresh leaf weight) from aphid-injured and non-injured regions, or partitioned regions of Arapahoe wheat leaves. A: The data from the 6-day samples $(n=4)$; B: The data from the 12-day samples $(n=4)$. Letters a-b denote a significant difference $(\alpha=0.05)$ among the aphid-injured regions (black bars) among the three types of infestations, while letters X-Z denote a significant difference among the non-injured regions (gray bars) among the infestations. *: Denotes the significant difference between the adjacent bars representing aphid-injured and non-injured regions within an infestation. RWA denotes the Russian wheat aphid, Diuraphis noxia, while BCOA denotes the bird cherry-oat aphid, Rhopalosiphum padi.

Chlorophyll $a / b$ ratio was significantly affected by aphid infestation duration $(\mathrm{F}=21.05$, $\mathrm{df}=1,18, \mathrm{P}=$ 0.0002) and the infestation type $(\mathrm{F}=13.15, \mathrm{df}=2,6, \mathrm{P}$ $=0.0064$ ) (Figures 4A, B). The influence of infestation type by duration interaction on the chlorophyll $a / b$ ratio was not significantly different $(\mathrm{F}=1.77, \mathrm{df}=1,18$, $\mathrm{P}=0.1983)$. Chlorophyll $a / b$ ratio between the damaged and non-damaged regions in $D$. noxia-infested leaves was not significantly $(\mathrm{F}=8.54$, df $=1,3, \mathrm{P}=$ 0.0614 ) different on day 6 (Figure $4 \mathrm{~A}$ ); however, on day $12, D$. noxia-infested leaves showed a significant ( $\mathrm{F}=14.32, \mathrm{df}=1,3, \mathrm{P}=0.0324)$ difference between the damaged and no-damaged leaf regions (Figure 4B).

Chlorophyll $(a+b) /$ carotenoid ratio also differed between aphid species $(\mathrm{F}=13.15$, $\mathrm{df}=2,6, \mathrm{P}=$ 0.0064), infestation duration ( $\mathrm{F}=21.05, \mathrm{df}=1,18, \mathrm{P}$ $=0.0002)$, and the infestation type by duration interaction $(\mathrm{F}=29.97$, $\mathrm{df}=2,18, \mathrm{P}<0.0001)$ (Figures 5A, B). Chlorophyll $(a+b)$ /carotenoid ratio between $D$. noxia-damaged and non-damaged regions was not significantly different on either sampling date (P-values $>$ 0.05) (Figures 5A, B).

Chlorophyll degradation enzyme assays. The in vitro assays of chlorophyllase, oxidative bleaching, and Mg-dechelatase activities showed that the three chlorophyll catabolic enzymes were affected differently by the aphid infestation type and duration. Chlorophyl- lase activity was significantly affected by the type of infestation ( $\mathrm{F}=18.69$, $\mathrm{df}=2,18, \mathrm{P}<0.0001)$ and infestation duration $(\mathrm{F}=14.13$, $\mathrm{df}=1,54, \mathrm{P}=0.0004)$ (Figures 6A, B). However, chlorophyllase activity was not significantly $(\mathrm{F}=3.08, \mathrm{df}=2,54, \mathrm{P}=0.0541)$ affected by the infestation type by duration interaction. Chlorophyllase activity was not significantly $(\mathrm{t}=2.36$, $\mathrm{df}=27, \mathrm{P}=0.1166$ ) different between the damaged and non-damaged regions (Figures 6A, B). Furthermore, while chlorophyllase activity from aphid-damaged regions was not significantly different among the three infestation types on either sampling date, chlorophyllase activity from the non-damaged regions varied among the three types of infestations and the two sampling dates. Chlorophyllase activity from the non-damaged regions of $D$. noxia-infested leaves was the same as the uninfested on day 6 (Figure 6A), while chlorophyllase activity was significantly higher from the nondamaged regions of $D$. noxia-infested leaves than from the uninfested on day 12 (Figure 6B).

The calculated oxidative bleaching activity from all leaf samples was negative, which is similar to our previous finding (Ni et al., 2001). We conclude that oxidative bleaching is not detected in vitro.

$\mathrm{Mg}$-dechelatase activity was significantly affected by infestation type $(\mathrm{F}=61.52$, $\mathrm{df}=2,18, \mathrm{P}<0.0001)$, duration $(\mathrm{F}=34.19$, $\mathrm{df}=1,54, \mathrm{P}<0.0001)$, and the infestation type by duration interaction $(\mathrm{F}=5.22$, $\mathrm{df}=1$, 

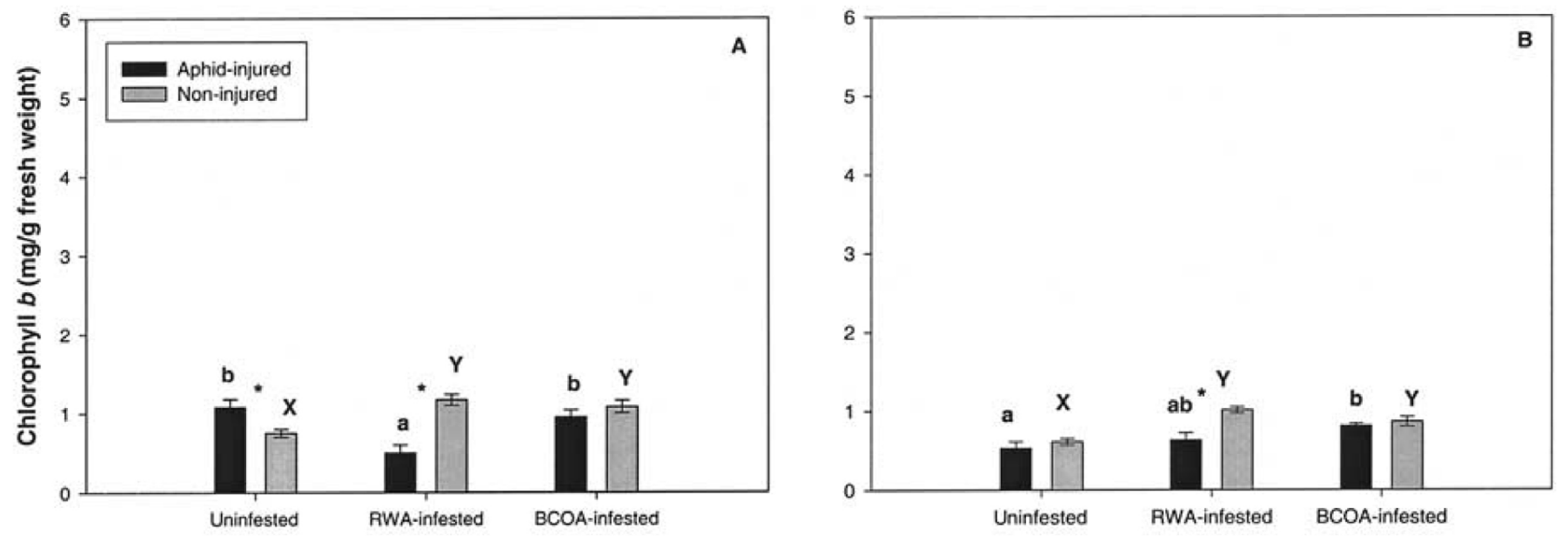

Treatment

Figure 2. Chlorophyll $b$ concentration ( $\mathrm{mg} \cdot \mathrm{g}^{-1}$ fresh leaf weight) from aphid-injured and non-injured regions, or partitioned regions of Arapahoe wheat leaves. A: The data from the 6-day samples $(n=4)$; B: The data from the 12-day samples $(n=4)$. For further information see legend of Figure 1.
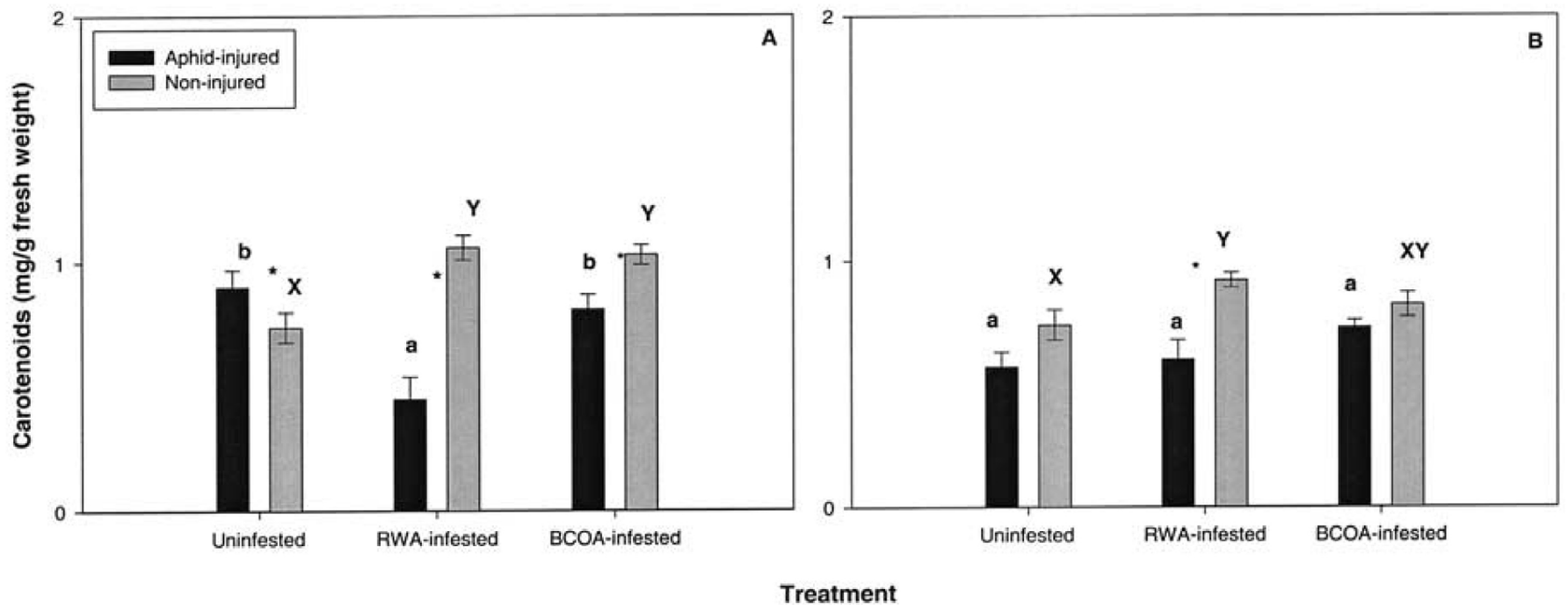

Figure 3. Carotenoid concentration ( $\mathrm{mg}^{-1} \mathrm{~g}^{-1}$ fresh leaf weight) from aphid-injured and non-injured regions, or partitioned regions of Arapahoe wheat leaves. A: The data from the 6-day samples $(n=4)$; B: The data from the 12-day samples $(n=4)$. For further information see legend of Figure 1.

54, $\mathrm{P}=0.0085)$. Diuraphis noxia-damaged leaf regions showed a significantly higher Mg-dechelatase activity in comparison with the equivalent regions in either $R$. padiinfested or the uninfested plants on both days 6 (Figure 7A) and 12 (Figure 7B). Furthermore, Mg-dechelatase activity in $D$. noxia-damaged regions was significantly ( $\mathrm{t}$ $=6.92, \mathrm{df}=9, \mathrm{P}=0.0301$ ) higher than the non-damaged regions on day 6 (Figure 7A), while $\mathrm{Mg}$ dechelatase activity was not significantly $(\mathrm{t}=0.02, \mathrm{df}=9, \mathrm{P}=0.9006)$ different on day 12 (Figure 7B). A significant increase in Mg-dechelatase activity between the sampling dates in the D. noxia-infested leaves were detected (Figures
7 A,B). The results of Mg-dechelatase activity suggests that wheat leaf response to $D$. noxia feeding is limited to aphid feeding sites initially and then become a whole leaf response as the infestation continues.

Total protein assays showed no significant difference between aphid-damaged and non-damaged regions ( $\mathrm{t}=$ 1.79 , $\mathrm{df}=27, \mathrm{P}=0.1923$ ), nor did infestation type by duration interaction $(\mathrm{F}=2.60$, $\mathrm{df}=2,54, \mathrm{P}=0.0834)$ affect total protein content. However, the total protein content was significantly different between the two sampling dates $(t=4.27, d f=54, P=0.0437)$. The results indicated that aphid feeding did not significantly affected 

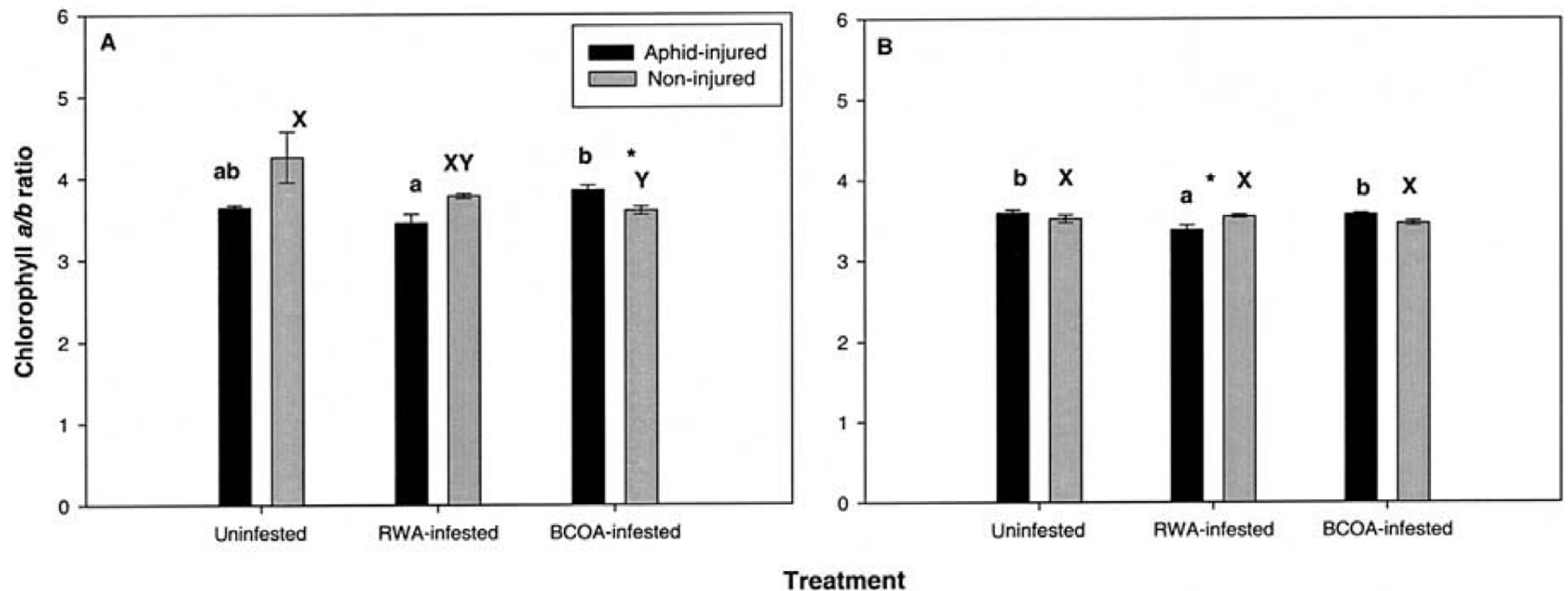

Figure 4. Chlorophyll $a / b$ ratio from aphid-injured and non-injured regions, or partitioned regions of Arapahoe wheat leaves. A, the data from the 6-day samples $(n=4)$; B, the data from the 12-day samples $(n=4)$. For further information see legend of Figure 1.
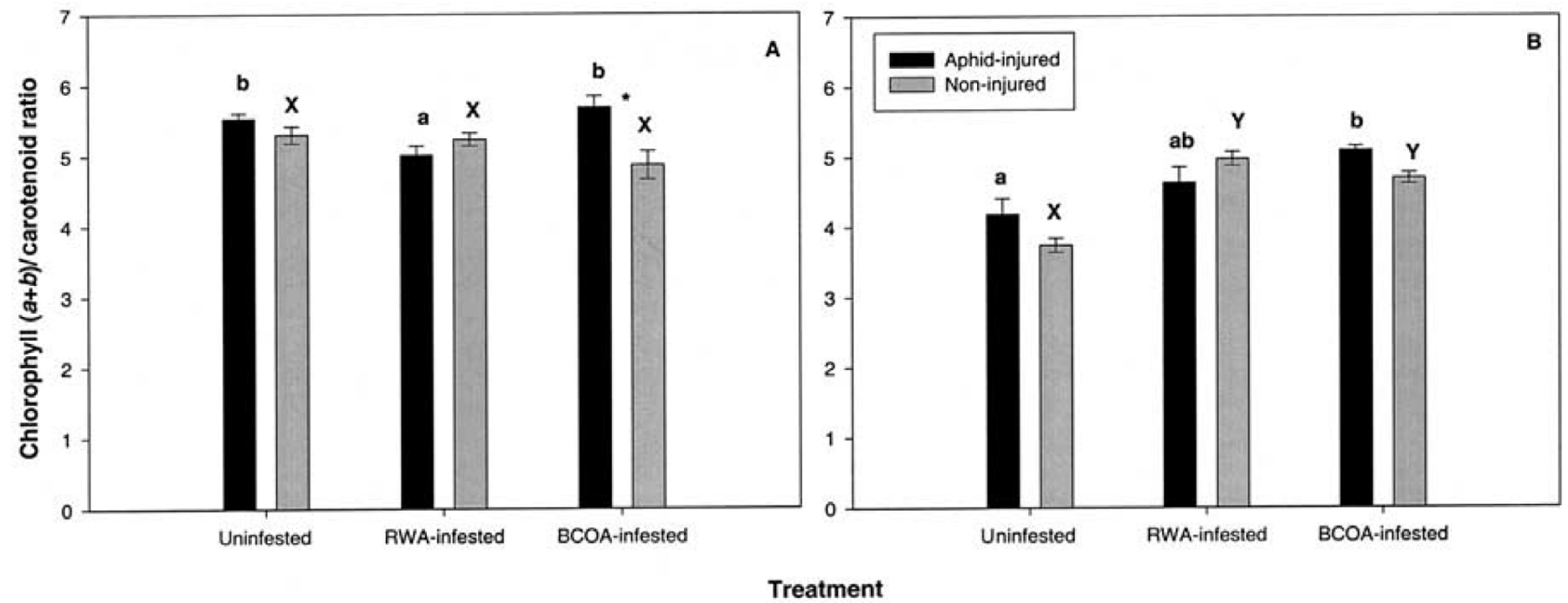

Figure 5. Chlorophyll $(a+b)$ /carotenoid ratio from aphid-injured and non-injured regions, or partitioned regions of Arapahoe wheat leaves. A: the data from the 6-day samples $(n=4)$; B: the data from the 12-day samples $(n=4)$. For further information see legend of Figure 1 .

total leaf protein content irrespective of aphid-damaged or non-damaged regions, while the duration of infestation did affect protein content significantly.

\section{Discussion}

The current experiment is a continuation of our previous work which showed that $D$. noxia-elicited leaf chlorosis was different from natural leaf senescence of plants (Ni et al., 2001). Photosynthetic pigment quantification data showed that the non-damaged regions of $D$. noxia-infested wheat leaves had a higher level of chlorophylls $a$ and $b$, and carotenoids in comparison with the equivalent regions of uninfested leaves. Non-damaged leaf regions of $D$. noxia-infested leaves respond to aphid feeding by compensating for aphid-elicited chlorophyll and carotenoid losses in the damaged regions. However, photosynthetic pigment compensation from the non-damaged regions of $R$. padi-infested plants was not as great as those observed on $D$. noxia-infested leaf regions.

Photosynthetic pigment quantification from Arapahoe (susceptible) wheat is similar to the findings reported on PI 137739 (D. noxia resistant plant introduction line), but not 'Stephens' (D. noxia susceptible cultivar) according to Rafi et al. (1997). Non-damaged leaf regions of PI 137739 showed a significantly higher total chlo- 

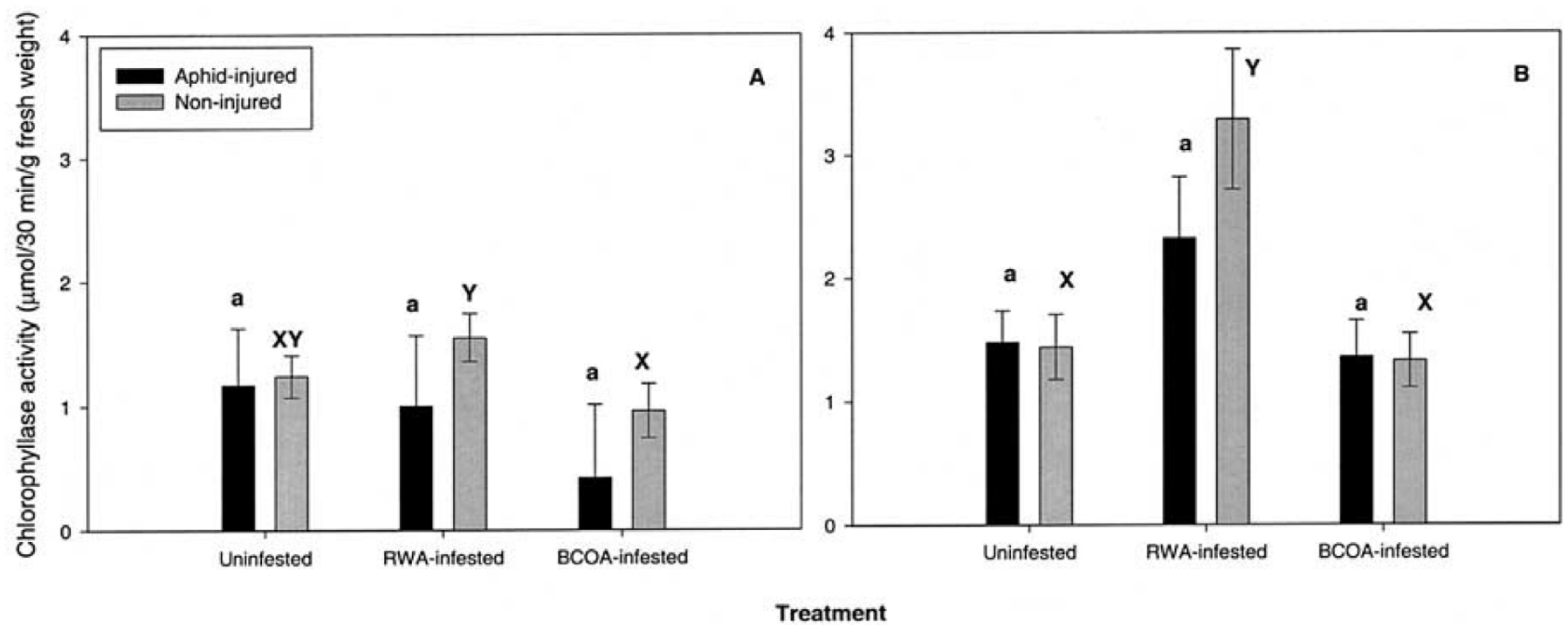

Figure 6. Chlorophyllase activity ( $\mu \mathrm{mol} \cdot 30-\mathrm{min}^{-1} \cdot \mathrm{g}^{-1}$ fresh leaf weight) from aphid-injured and non-injured regions, or partitioned regions of Arapahoe wheat leaves. A: the data from the 6-day samples $(\mathrm{n}=10)$; B: the data from the 12-day samples $(\mathrm{n}=10)$. For further information see legend of Figure 1.
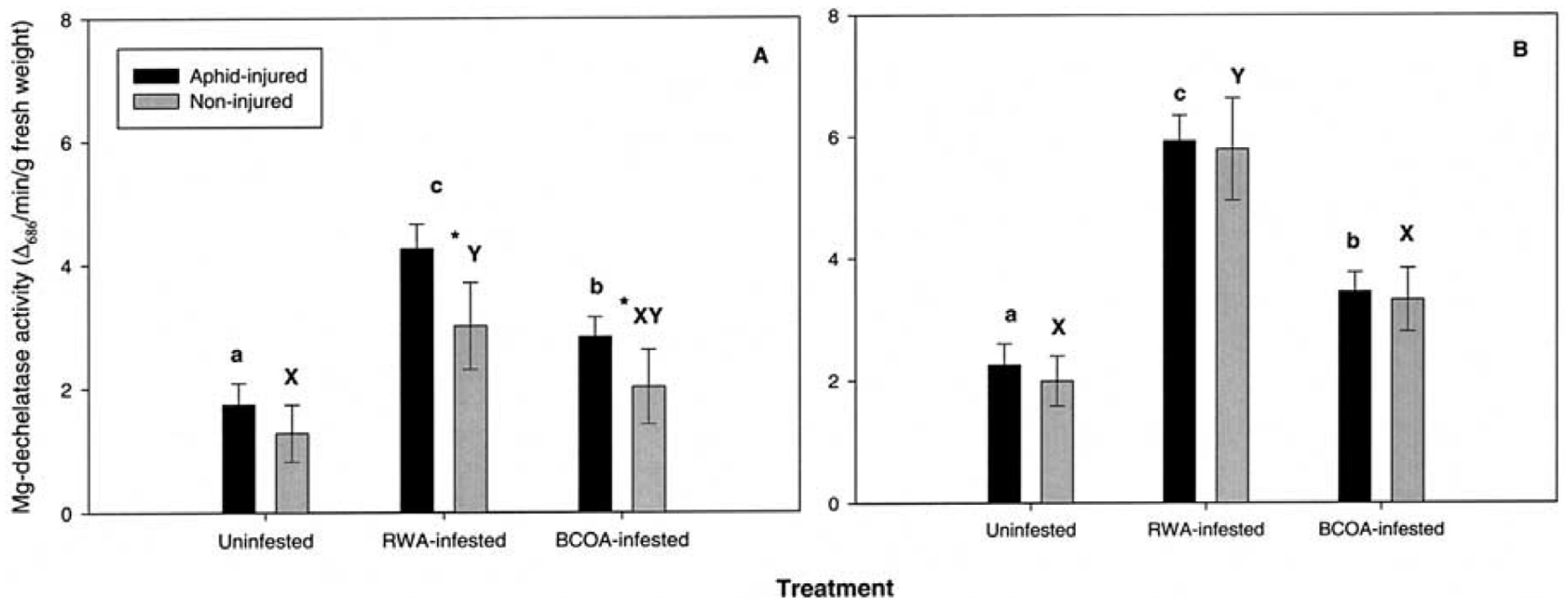

Figure 7. Mg-dechelatase activity (A686 $\bullet \mathrm{min}^{-1} \cdot \mathrm{g}^{-1}$ fresh leaf weight) from aphid-injured and non-injured regions, or partitioned regions of Arapahoe wheat leaves. A: the data from the 6-day samples $(n=10)$; B: the data from the 12-day samples $(n=10)$. For further information see legend of Figure 1.

rophyll content, however, no differences in total chlorophyll content were detected between $D$. noxia-damaged and the non-damaged regions from a susceptible Stephens wheat (Rafi et al., 1997). The difference between our current findings and the previous report could be caused by the differences in aphid placement on the leaf and number of aphids. We allowed aphids to settle naturally on younger wheat leaves, while Rafi et al. (1997) confined aphids on the mature leaf blades. Furthermore, we separated chlorophylls $a$ and $b$ and also determined carotenoid concentration, while Rafi et al. (1997) only examined the total chlorophyll content.
The level of carotenoids showed a similar pattern as the chlorophylls did, that is, the leaf regions with a high level of chlorophylls were accompanied with higher levels of carotenoids. Because carotenoids participate in light harvesting and protect the photosynthetic apparatus from photo oxidative damage by quenching triplet state chlorophyll molecules and scavenging reactive oxygen species such as singlet oxygen (Biswal et al., 1994; Malkin \& Niyogi, 2000), the similar pattern of all three photosynthetic pigments is not surprising.

The chlorophyll $a / b$ ratio changed with infestation duration. This finding seems to be explained by the report 
from Boffey et al. (1980) that chlorophyll a/b ratio varies in wheat from the basal meristem to more mature tissues further up the leaf. Younger portions The chlorophyll $a / b$ ratio changed with infestation duration. This finding seems to be explained by the have a higher chlorophyll $a / b$ ratio than the older portions of the leaf, and chlorophyll biosynthesis rate per plastid in the first leaf of wheat seedlings increases with cell age. Diuraphis noxia feeding elicited a significantly lower chlorophyll $a / b$ ratio in the damaged regions in comparison with the non-damaged regions only from long-infestation samples, indicating that $D$. noxia feeding elicited a significant impact on wheat leaf photosynthesis and consequently plant senescent rate. Chlorophyll $(\mathrm{a}+\mathrm{b})$ /carotenoid ratio was not significantly different between the aphid-damaged and nondamaged leaf regions. Aphid-elicited chlorosis differs from natural plant senescence where chlorophyll catabolism unmasks carotenoids and leads to a lower chlorophyll $(a+b)$ )/carotenoid ratio (Dangl et al., 2000).

The assays of chlorophyll degradation enzymes indicated that $D$. noxia feeding significantly increased $\mathrm{Mg}$ dechelatase activity on both sampling dates in the damaged and non-damaged leaf regions in comparison with the uninfested leaves. No oxidative bleaching activity was detected. Although chlorophyllase activity was detected, there was no significant difference between the damaged and non-damaged leaf regions within an infestation type. The dynamic change of chlorophyllase activities from the non-damaged regions of the infested plants suggests that $D$. noxia elicits a cascade of physiological events surrounding its feeding sites in susceptible wheat plants, while $R$. padi did not. The wheat plant response to $D$. noxia feeding was limited to its feeding sites at the beginning of the infestation (up to day 6) because Mgdechelatase activity only from aphid-damaged regions was significantly higher in comparison with the non-damaged regions. In contrast, there is no difference in Mg-dechelatase activity between the damaged and the non-damaged regions of $D$. noxia-infested leaves from the long-infestation (12 day) samples, although $D$. noxiainfested plants showed a significantly higher Mg-dechelatase activity than either $R$. padi-infested or the uninfested plants. The assays clearly demonstrate the dynamic nature of plant responses to aphid feeding, which was initially a localized response limited to the site of feeding, and then, transformed into a whole leaf response. Furthermore, the data also indicate that $D$. noxia may elicit a signaling chemical transduction between the damaged and non-damaged regions of the infested leaves.

\section{Acknowledgements}

We thank Y. Liu for her assistance on conducting experiments, and maintaining the plant and aphid colonies. We also thank S. Blodgett, J. Littlefield, and K. O'Neill (Montana State University), and two anonymous reviewers for their critical review of the manuscript. The research reported here was supported in part by the USDA-NRICGP 99-35302-8628, and an interdisciplinary research grant (NEB 17064) from Agricultural Research Division, University of Nebraska-Lincoln. This is Journal series number 2002-08 from the Montana Agricultural Experiment Station.

\section{References}

Almela, L., J. A. Fernández-López \& M. J. Roca, 2000. High-performance liquid chromatographic screening of chlorophyll derivatives produced during fruit storage. Journal of Chromatography A 870: 483-489.

Bertrand, M. \& B. Schoefs, 1997. Working with photosynthetic pigments: problems and precautions. In: M. Pessarakli (ed.), Handbook of Photosynthesis. Marcel Dekker, Inc. New York, pp. 151-172.

Biswal, B., L. J. Rogers, A. J. Smith \& H. Thomas, 1994. Carotenoid composition and its relationship to chlorophyll and D1 protein during leaf development in a normally senescing cultivar and a stay-green mutant of Festuca pratensis. Phytochemistry 37: 1257-1262.

Boffey, S. A. G. Selldén \& R. M. Leech, 1980. Influence of cell age on chlorophyll formation in light-grown and etiolated wheat seedlings. Plant Physiology 65: 680-684.

Bollag, D. M. \& S. J. Edelstein, 1991. Protein concentration determination. In: D. M. Bollag \& S. J. Edelstein (eds), Protein Methods. Wiley-Liss, New York, pp. 45-69.

Dangl, J. L., R. A. Dietrich \& H. Thomas, 2000. Senescence and programmed cell death. In: B. B. Buchanan, W. Gruissem \& R. L. Jones (eds), Biochemistry and Molecular Biology of Plants. American Society of Plant Physiologists, Rockville, MD, pp. 1044-1100.

Drążkiewicz, M., 1994. Chlorophyllase: occurrence, functions, and mechanism of action, effects of external and internal factors. Photosynthetica 30: 321-331.

Ellsworth, R. K., 1971. Increase in photosynthetic activity during the formation of the first node roots and first tiller in Sorghum saccharatum (L.) Moench. Photosynthetica 5: 233-240.

Iriyama, K., N. Ogura \& A. Takamiya, 1974. A simple method for extraction and partial purification of chlorophyll from plant material using Dioxane. Journal of Biochemistry 76: 901-904.

Janave, M. T., 1997. Enzymatic degradation of chlorophyll in cavendish bananas: In vitro evidence for two independent degradative pathways. Plant Physiology and Biochemistry 35: 837-846.

Malkin, R. \& K. Niyogi, 2000. Photosynthesis. In: B. B. Buchanan,

W. Gruissem \& R. L. Jones (eds), Biochemistry and Molecular Biology of Plants. American Society of Plant Physiologists, Rockville, MD, pp. 568-628. 
Matile, P., S. Hörtensteiner \& H. Thomas, 1999. Chlorophyll degradation. Annual Review of Plant Physiology and Plant Molecular Biology 50: 67-95.

Mihailović, N, M. Lazarević, Ž. Dželetović, M. Vučković \& M. Đurđević, 1997. Chlorophyllase activity in wheat, Triticum aestivum L. leaves during drought and its dependence on the nitrogen ion form applied. Plant Science 129: 141-146.

Ni, X., S. S. Quisenberry, J. Markwell, T. Heng-Moss, L. Higley, F. Baxendale, G. Sarath \& R. Klucas, 2001. In vitro enzymatic chlorophyll catabolism in wheat elicited by cereal aphid feeding. Entomologia Experimentalis et Applicata 101: 159-166.

Rafi, M. M., R. S. Zemetra \& S. S. Quisenberry, 1997. Feeding damage of Russian wheat aphid on resistant and susceptible wheat genotypes. Cereal Research Communications 25: 63-68.

Rüdiger, W., 1997. Chlorophyll metabolism: from outer space down to the molecular level. Phytochemistry 46: 1151-1167.
SAS Institute, 1989. SAS/STAT user's guide. SAS Institute, Cary, NC.

Tanaka, K., T. Kakuno, J. Yamashita \& T. Horio, 1982. Purification and properties of chlorophyllase from greened rye seedlings. Journal of Biochemistry 92: 1763-1773.

Tsuchiya, T., H. Ohta, K. Okawa, A. Iwamatsu, H. Shimada, T. Masuda \& K. Takamiya, 1999. Cloning of chlorophyllase, the key enzyme in chlorophyll degradation: finding of a lipase motif and the induction by methyl jasmonate. Proceedings of National Academy of Sciences-USA 96: 15362-15367.

Vicentini, F., F. Iten \& P. Matile, 1995. Development of an assay for Mg-dechelatase of oil seed rape cotyledons, using chlorophyllin as the substrate. Physiologia Plantarum 94: 57-63.

Zadoks, J. C., T. T. Chang \& C. F. Konzak, 1974. A decimal code for the growth stages of cereals. Weed Research 14: 415-421. 